\title{
Islet Cell 512 Antigen Measurement
}

National Cancer Institute

\section{Source}

National Cancer Institute. Islet Cell 512 Antigen Measurement. NCI Thesaurus. Code C81986.

The determination of the amount of islet cell 512 antigen present in a sample. 